Article

\title{
Glendonite-Like Carbonate Aggregates from the Lower Ordovician Koporye Formation (Russian Part of the Baltic Klint): Detailed Mineralogical and Geochemical Data and Paleogeographic Implications
}

\author{
Kseniia Mikhailova ${ }^{1}$, Kseniia Vasileva ${ }^{1, *}$, Petr Fedorov ${ }^{1}{ }^{\circledR}$, Victoria Ershova ${ }^{1}$, \\ Oleg Vereshchagin ${ }^{1}\left(\mathbb{D}\right.$, Mikhail Rogov $^{2}\left(\mathbb{D}\right.$ and Boris Pokrovsky ${ }^{2}$ \\ 1 Institute of Earth Sciences, St. Petersburg State University, Universitetskaya nab. 7/9, \\ 199034 St. Petersburg, Russia \\ 2 Geological Institute of RAS, Pyzhevski Lane 7, 119017 Moscow, Russia \\ * Correspondence: k.vasilyeva@spbu.ru; Tel.: +7-904-631-88-80
}

Received: 22 July 2019; Accepted: 26 August 2019; Published: 29 August 2019

check for updates

\begin{abstract}
Stellate and plate-like carbonate bodies, traditionally called anthraconites, are found throughout the Baltic-Ladoga Klint in bituminous shale of the Koporye Formation (Tremadocian, Lower Ordovician). Although this time interval is usually considered as a greenhouse, there is some evidence for the existence of at least temporary cold conditions during the Cambrian-Ordovician. However, the origin of anthraconites is still strongly debated. We studied the mineralogical, petrographic, cathodoluminescence, geochemical, and isotopic characteristics of anthraconites from five sections of the Russian part of the Baltic paleobasin. A close similarity between the morphological, petrographic, cathodoluminescence, and isotopic characteristics of the studied anthraconites with those of glendonites allow us to suggest that these bodies formed in a similar paleo-environment and should be considered as pseudomorphs of the mineral ikaite. The oxygen and carbon isotope ratios reveal that ikaite precipitation occurred in low-temperature conditions on the seafloor. The carbon isotopic values reveal influence of inorganic seawater carbon along with organic matter decomposition and/or methane oxidation during ikaite-glendonite transformations. The oxygen isotopic composition significantly changed after deposition due to meteoric diagenesis. We propose that the studied Tremadocian anthraconites formed under a region of upwelling, where cold phosphate-rich deep waters rose to the relatively shallow part of the Baltic paleobasin, providing favorable conditions for ikaite precipitation. Based on our cathodoluminescence study, we suggest that ikaite was transformed to calcite over several stages during diagenesis. Mineralogical studies also reveal that primary calcite was transformed to sulfate (gypsum) or dolomite during late superimposed processes.
\end{abstract}

Keywords: glendonite; carbonate diagenesis; isotopes; Ordovician; black shales

\section{Introduction}

The reconstruction of past climates based on geochemical proxy data has become increasingly popular over the past couple of decades. This study focuses on the origin of carbonate bodies called anthraconites within the lower Tremadocian black shale (Koporye Formation), also known under the traditional name of the Dictyonema Shale, of the northwestern Russian Platform (Leningrad Oblast), and their paleogeographic significance.

In the Tremadocian (Early Ordovician), the study region was located across the western part of the Baltica continent at temperate latitudes [1]. The western margin of Baltica was surrounded by the Tornquist Ocean [1]. Based on oxygen isotope data, a warm greenhouse climate prevailed during the 
Tremadocian, resulting in anoxic conditions at depth [2-4]. A global marine transgression in the early Tremadocian facilitated black shale deposition across a significant portion of the submerged continental shelves [5]. The Dictyonema Shale has been extensively studied since the middle of the 19th century by mineralogical and geochemical methods (e.g., [6]). Although historically "anthraconite" was used as a common name for any bituminous limestones, which are very common in the Early Paleozoic of Baltoscandia (i.e., $[7,8]$ ), in the studied area this term is used solely for stellate nodules composed of radiating carbonate and plate-like bodies consisting of large vertically oriented crystals. Moreover, there is no overall consensus on the mechanism of genesis for anthraconites. Here we present a detailed description of the mineralogical, petrographic, geochemical, and isotopic characteristics of the Lower Tremadocian anthraconites that allow us to propose a model for their formation.

\section{Brief Review of Early Paleozoic Climate and Glendonite Findings}

Early Paleozoic glendonites (or suspected glendonites) were insufficiently known until now, but nevertheless their records were mentioned and/or imaged in publications since the second part of the 19th century. Lower Cambrian glendonite-like pseudomorphs from Sweden were imaged and described by [9] in association with other markers of cold climates [10]. The same author subsequently discussed possible glendonite affinities of these pseudomorphs [11], although their morphology displays some differences from true glendonites, and the nature of these "sand crosses" remains unclear. Upper Cambrian records of "Pseudogaylussit" (the common name for glendonites used in the 19th century) were described from Bornholm island (Denmark) by Stolley [12] and Callisen [13], while numerous glendonite-like pseudomorphs from the Upper Cambrian of Sweden were imaged by Hadding ([7], Figures 73, 75 and 76 therein) as "anthraconite" or "barite". Very recently, Choh [14] reported glendonite occurrences from the uppermost Cambrian of Korea. Lower Ordovician stellate pseudomorphs from Norway were illustrated by Brøgger [15], and "pseudomorphs" (without images) are considered as a typical feature of the Tremadocian black shales of the Oslo region [16]. All aforementioned glendonite occurrences, however, remain doubtful, as they were not studied in detail and only some of these records were well-illustrated.

Although Cambrian-Early Ordovician climate is generally considered as a greenhouse [17,18], plenty of evidence for climate oscillations and even the presence of glaciations in the Early Cambrian and Late Cambrian have been identified in recent decades [19]. This includes the presence of tillites and abundant dropstones, as well as specific sedimentary structures (ice-push lineations and structures implying frozen sediment) in the Early Cambrian $[10,20,21]$, and evidence for freezing conditions even in the relatively low-latitudes in the Late Cambrian [22].

\section{Geological Background}

The study area is located in the north-western part of the Russian Platform (Figure 1). Archean-Paleoproterozoic basement, composed of intensely deformed granite and gneiss, crops out in the northern part of the study area. Basement is unconformably overlain by Neoproterozoic-Paleozoic sedimentary rocks up to $300 \mathrm{~m}$ thick [23]. Neoproterozoic sediments were deposited on the eroded basement surface, comprising sandstones and shales with gravelly conglomerates at the base. Cambrian clayey-sandy deposits unconformably overlie Neoproterozoic rocks, whilst Ordovician deposits overlie the Uppermost Cambrian-Lower Ordovician Tosna Formation, beginning with transgressive black shales at the base, coarsening upward into fine-grained quartz and glauconitic sandstones (Ordovician Leetse Formation, Figure 2). The middle and upper parts of the Lower Ordovician strata comprise dolomitized limestone [23-25]. 


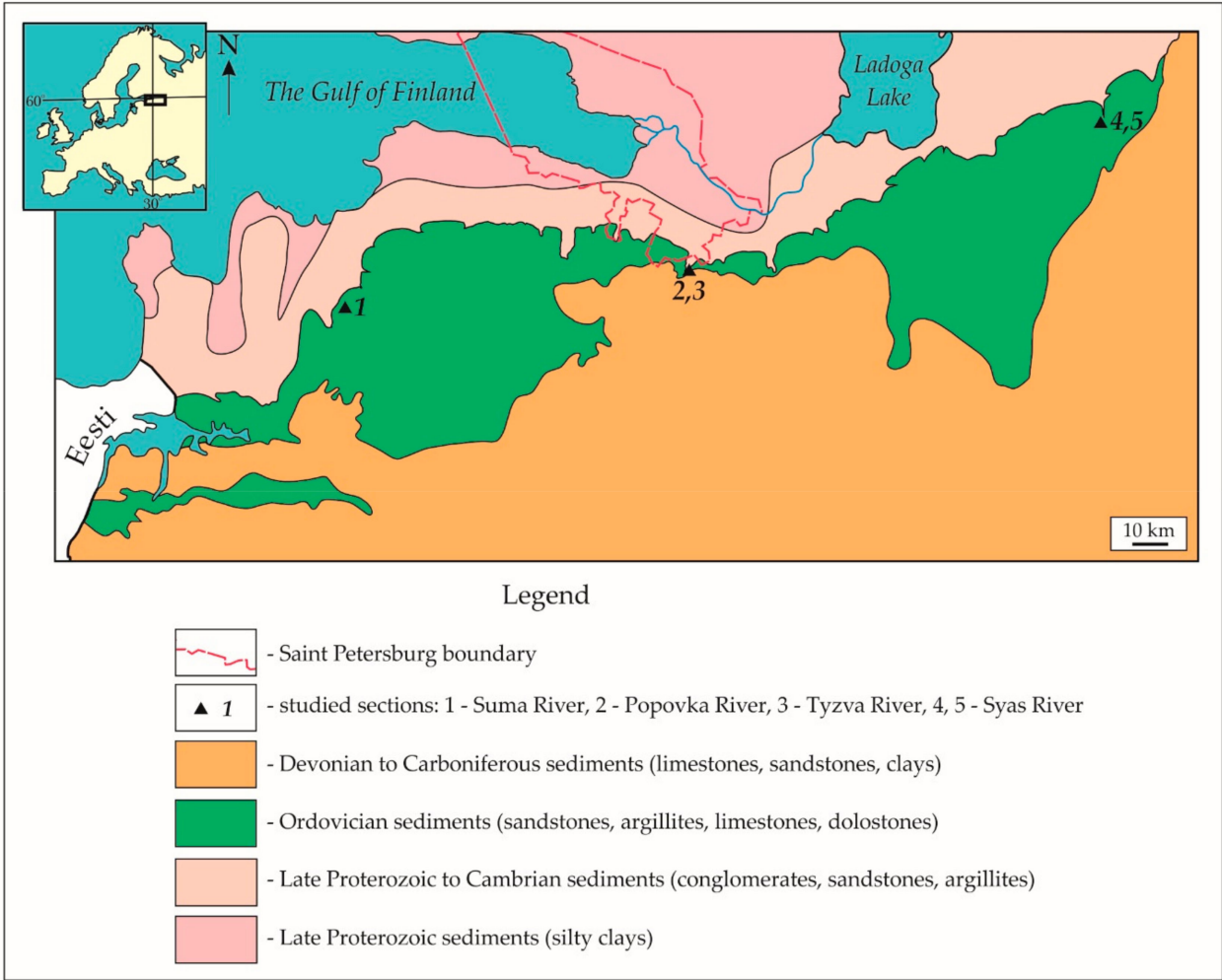

Figure 1. Location of studied sections in the Russian part of the Baltic-Ladoga Klint.

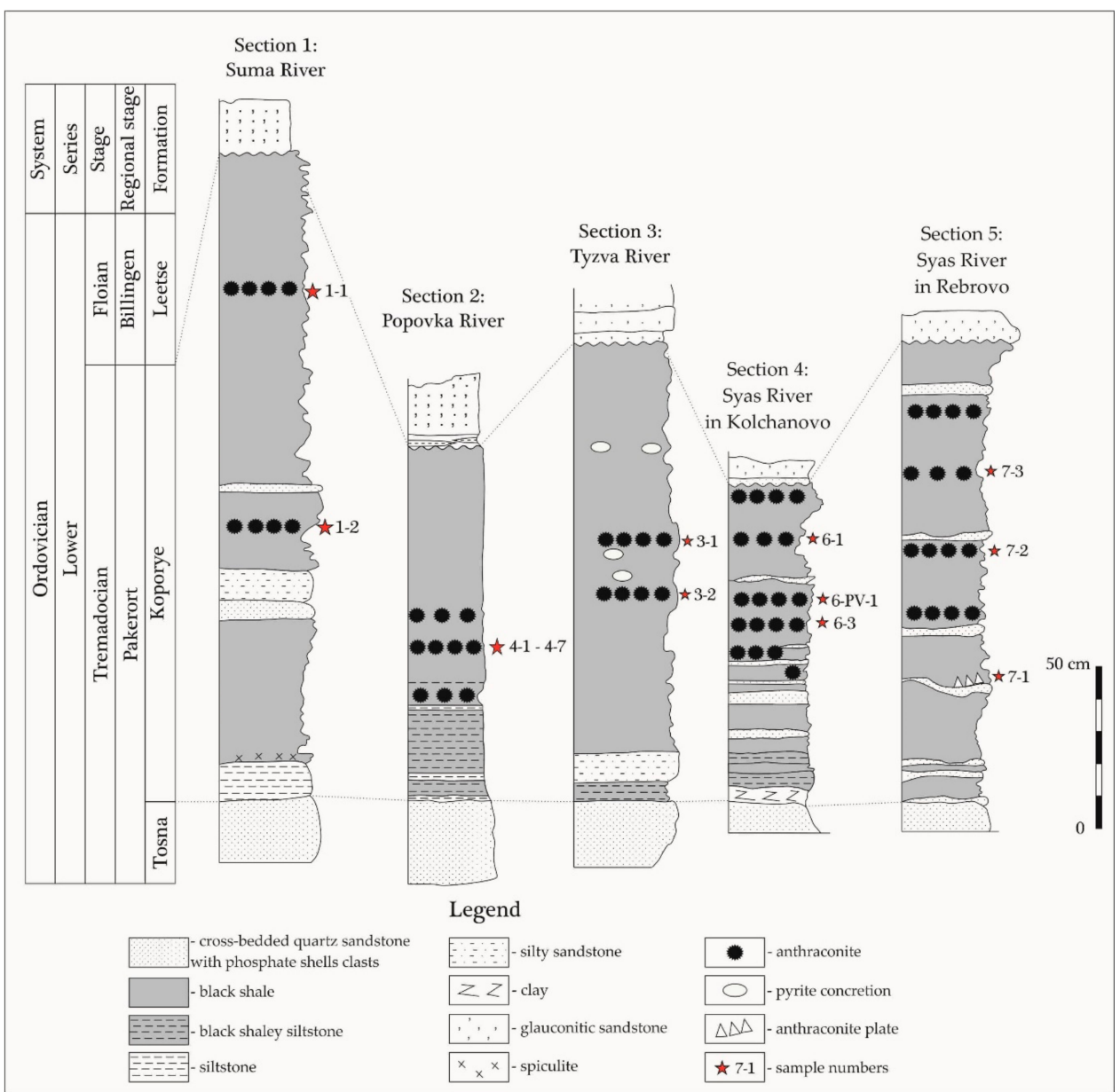

Figure 2. Stratigraphic sections of studied outcrops, with the location of studied samples. 
The shales of the Koporye Formation were traced across the entire study area. The shales represent a transgressive succession, lying conformably on uppermost Furongian-lowermost Ordovician Obolus sandstone (Tosna Formation) and overlain by the upper Tremadocian thin sandstone of the Nazya Formation or the uppermost Tremadocian-lower Furongian glauconitic sandstone of the Leetse Formation. The Koporye Formation is subdivided into two parts [26]. The lower part consists of interbedded fine-grained sandstone, siltstone and brownish gray to black clay, containing abundant graptolite remains (up to $2.4 \mathrm{~m}$ ). The upper part consists of homogeneous massive black shale with numerous anthraconites and pyrite concretions. In the western part of the study area, thin spicule-rich interbeds were found. The thickness of the upper part reaches $4 \mathrm{~m}$. The Koporye Formation encompasses graptolite zone Rhabdinopora flabelliformis (s.l.), which coincides with conodont zone Cordylodus angulatus-Cordylodus rotundatus [26].

\section{Overview of Previous Studies of Anthraconites}

Surprisingly, such remarkable objects as anthraconites rarely attract special attention. They were considered as early diagenetic concretions [7]. Loog [27] suggested that these were dolomite pseudomorphs after calcite. Another model was proposed by Tugarova and Platonov [28], who studied anthraconites from the lower Tremadocian shale of the Leningrad Region (in the outcrops of Syas River), and suggested that oncolites could form the nucleus around which the nodule crystallized. The most recent paper dedicated to glendonite occurrence and distribution was published by Popov et al. [29]. The aforementioned authors assume that ikaite was precipitated in a thermally stratified basin with a very strong temperature gradient, resulting in both "hot" conodonts and glendonites being preserved in the black shales.

\section{Materials and Methods}

To evaluate differences in anthraconites, samples from five sections cropping out along the Baltic-Ladoga Klint (an erosion escarpment in the Ordovician limestone extending through the Baltic sea to Ladoga Lake; Figures 1 and 2) were taken. The stratigraphic position of the anthraconites was carefully documented. The samples were subjected to mineralogical, petrographic, cathodoluminescence, isotopic, and geochemical studies. Polished thin-sections were examined under the polarizing light microscope Olimpus BX-53, and cathodoluminescence petrography $(C L)$ was performed using a CL8200 Mk5-2 Optical CL System, operating at an accelerating voltage of 6-13 kV and current of $324 \mu \mathrm{A}$. The chemical composition of the polished samples was studied in the "Geomodel" resource center (RC) of Saint-Petersburg State University (SPbSU) by means of a Hitachi S-3400N scanning electron microscope equipped with an Oxford Instruments AzTec Energy X-Max 20 energy dispersive (EDX) spectrometer. EDX spectra were obtained under $20 \mathrm{kV}$ accelerating voltage and $2 \mathrm{nA}$ beam current and acquisition time of $30 \mathrm{~s}$ per spectrum.

For mineralogic and isotopic analyses, samples from the inner unweathered parts of the anthraconites were taken using a microdrill. X-ray diffraction $(\mathrm{XRD})$ patterns of rock samples were recorded on a Rigaku Miniflex II diffractometer (CuK $\alpha$ radiation, $3^{\circ} / \mathrm{min}$ scan speed) in the Center of $\mathrm{X}$-ray diffraction studies (Saint Petersburg State University Research Park). Carbon and oxygen isotope data were generated at the Geological Institute of the Russian Academy of Sciences, Laboratory of Geochemistry of Isotope and Geochronology, Moscow. The Thermo electron system was used, including a Delta V Advantage Mass-Spectrometer with Gas-Bench-II, with analytical precision for both $\delta^{18} \mathrm{O}$ and $\delta^{13} \mathrm{C}$ of $\pm 0.2 \%$ o (for details of analytical technique see [30]).

\section{Results}

\subsection{Morphologies of Studied Anthraconites}

The studied anthraconites are characterized by a wide range of morphology. The first group is the most abundant and represents nodules with a diameter of $5-25 \mathrm{~cm}$. The interior of the anthraconites is 
characterized by a stellate structure (Figure 3b,c). Cross sections of the crystals are square, rhombic, triangular or irregular (Figure 3b). Individual crystals 1-1.5 cm in length represent the second group (Figure 3e). Single findings (third group) represent brush-like plates with crystals $3-5 \mathrm{~cm}$ in length (Figure 3d).

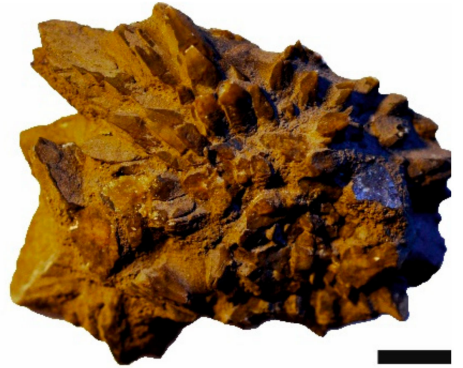

(a)

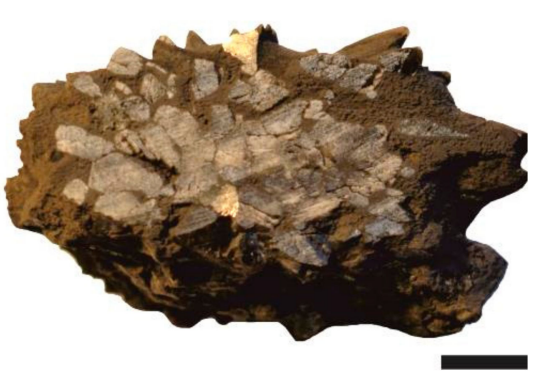

(b)

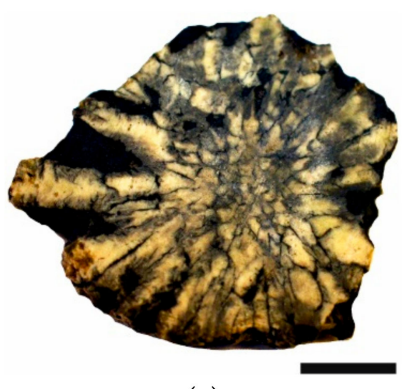

(c)

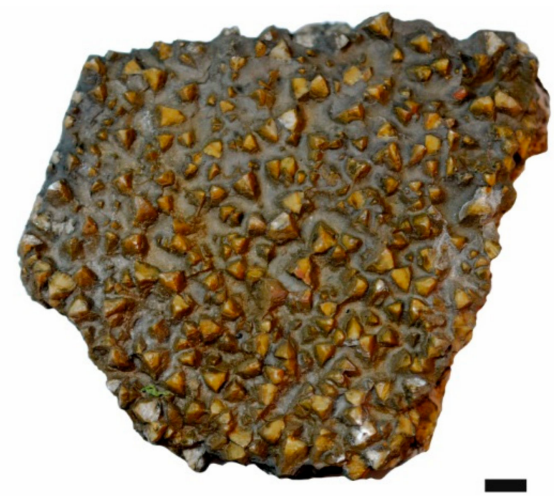

(d)

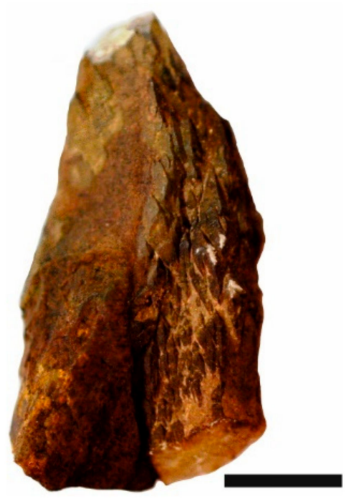

(e)

Figure 3. Morphology of studied anthraconites: (a-c) stellate-like anthraconites, (a) surface, $(\mathbf{b}, \mathbf{c})$ cross sections; (d) brush-like plate of calcite crystals; (e) anthraconite single crystal. Scale bar is $10 \mathrm{~mm}$.

\subsection{Mineralalogy of Anthraconites Revealed by X-ray Diffraction and Microprobe Analysis}

Stellate anthraconites were subjected to mineralogical analyses. X-ray diffraction analyses revealed several main types of the studied samples. The first group combines samples composed of calcite (all samples from the Syas River and samples 3-1-1 to 3-1-5 from Tyzva River, Table 1). The anthraconites from the second group are composed of dolomite (samples 1-1-2 and 1-2-2 from Suma River). Samples from Popovka River (4-1-4-7) and two samples from Tyzva River (3-2-1 and 3-2-8) reveal the most diverse mineralogy. Samples 3-2-1, 4-2, 4-3, and 4-5 are composed of calcite with minor or trace amounts of dolomite, gypsum, and pyrite. Samples 3-2-8 and 4-6 are composed of dolomite, calcite, gypsum, and pyrite. Samples 4-1 and 4-4 do not contain any carbonate phases and are composed of gypsum and pyrite. All of the studied samples contain trace amounts of quartz and K-feldspar grains.

Microprobe analyses were carried out for samples from each group (1-1-2, 3-1-1, 4-6, 6-1-2, see Table 2 and Figure 4). The results of this study reveal cerianite- $(\mathrm{Ce})\left(\mathrm{CeO}_{2}\right)$ in microfractures (sample 4-6; Figure 4a) and fluorapatite in sample 6-1-2 (Figure 4b). Besides that, the chemical composition of carbonates was studied. We show that calcite is composed of almost pure $\mathrm{CaCO}_{3}$, with just a small admixture of $\mathrm{Mg}(<1 \mathrm{wt}$. \% MgO). Dolomite from sample 4-6 contains a significant amount of Fe and $\mathrm{Mn}$, however in all cases $\mathrm{Mg}>\mathrm{Fe}>>\mathrm{Mn}\left(\mathrm{FeO}_{\text {tot }} \sim 18 \mathrm{wt}\right.$. \%, $\mathrm{MnO}_{\text {tot }} \sim 5 \mathrm{wt}$ \% $)$. 
Table 1. Mineralogy of the studied anthraconite samples (data obtained by X-ray diffraction).

\begin{tabular}{|c|c|c|c|c|c|c|c|c|c|c|c|}
\hline \multirow{2}{*}{ No } & \multirow{2}{*}{ Sample } & \multirow{2}{*}{ Location } & \multicolumn{9}{|c|}{ Phase } \\
\hline & & & Cal-1 & Cal-2 & Dol & Qtz & Gyp & Pyr & Zeo & Fap & Kfsp \\
\hline 1 & $1-1-2$ & \multirow{2}{*}{ Suma River } & & & $\boldsymbol{\square}$ & \pm & & & & & \\
\hline 2 & $1-2-2$ & & & & $\mathbf{\square}$ & \pm & & & & & \\
\hline 3 & $3-1-1$ & \multirow{7}{*}{ Tyzva River } & 口 & & & \pm & & & & & \pm \\
\hline 4 & $3-1-2$ & & 口 & & & \pm & & & & & \pm \\
\hline 5 & $3-1-3$ & & 口 & & & \pm & & & & & \pm \\
\hline 6 & $3-1-4$ & & घ & & & \pm & & & & & \pm \\
\hline 7 & $3-1-5$ & & घ & & & \pm & & & & & \pm \\
\hline 8 & $3-2-1$ & & a & & & \pm & $\square$ & $\square$ & & & \pm \\
\hline 9 & $3-2-8$ & & $\square$ & & - & \pm & $\square$ & & & & \pm \\
\hline 10 & $4-1$ & \multirow{7}{*}{$\begin{array}{l}\text { Popovka } \\
\text { River }\end{array}$} & & & & \pm & $\mathbf{\square}$ & $\boldsymbol{\square}$ & & & \\
\hline 11 & $4-2$ & & 口 & & \pm & \pm & ㅁ & & & & \\
\hline 12 & $4-3$ & & घ & & \pm & \pm & 口 & & & & \\
\hline 13 & $4-4$ & & & & & \pm & $\mathbf{\square}$ & घ & \pm & & \\
\hline 14 & $4-5$ & & - & & घ & \pm & ㅁ & & & & \\
\hline 15 & $4-6$ & & $\square$ & & $\boldsymbol{\square}$ & \pm & ㅁ & & & & \\
\hline 16 & $4-7$ & & $\square$ & & $\square$ & \pm & a & & & & \\
\hline 17 & $6-1-1$ & \multirow{4}{*}{$\begin{array}{l}\text { Syas River in } \\
\text { Rebrovo }\end{array}$} & 口 & $\mathbf{\square}$ & & \pm & & & & & \\
\hline 18 & $6-1-2$ & & - & & & \pm & & & & & \\
\hline 19 & 6-PV-1 & & $\mathbf{\square}$ & & & \pm & & & & & \\
\hline 20 & $6-3-2$ & & - & & & \pm & & & & & \pm \\
\hline 21 & $7-1$ & \multirow{6}{*}{$\begin{array}{l}\text { Syas River in } \\
\text { Kolchanovo }\end{array}$} & 口 & & & $\square$ & & & & \pm & \\
\hline 22 & $7-2-1$ & & $\square$ & & & \pm & & & & & \pm \\
\hline 23 & $7-2-2$ & & $\mathbf{\square}$ & & & \pm & & & & & \pm \\
\hline 24 & $7-3-1$ & & 口 & & & \pm & & & & & \pm \\
\hline 25 & $7-3-2$ & & 口 & & & \pm & & & & & \pm \\
\hline 26 & $7-3-3$ & & 口 & & & \pm & & & & & \pm \\
\hline
\end{tabular}

Table 2. Mineralogy of the studied anthraconite samples (data obtained by microprobe analyses).

\begin{tabular}{|c|c|c|c|c|c|c|c|c|c|}
\hline \multirow{2}{*}{ No } & \multirow{2}{*}{ Sample } & \multicolumn{8}{|c|}{ Phase } \\
\hline & & Cal & Dol & Qtz & Gyp & Pyr & Mic & Cer & Fap \\
\hline 1 & $1-1-2$ & & 口 & \pm & & \pm & \pm & & \\
\hline 3 & $3-1-1$ & 口 & & \pm & & \pm & \pm & & \\
\hline 15 & $4-6$ & 口 & 口 & & ㅁ & \pm & \pm & ㅁ & \\
\hline 18 & $6-1-2$ & 口 & \pm & & & & & & \pm \\
\hline
\end{tabular}

Note: Cal—calcite, Dol—dolomite, Gyp-gypsum, Pyr-pyrite, Mic-illite/muscovite, Ce-cerianite-(Ce),

Fap-fluorapatite. -main phase, $\square$-minor phase, \pm - trace. 


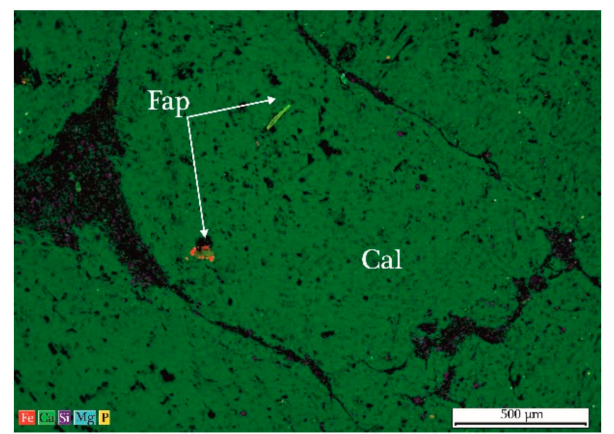

(a)

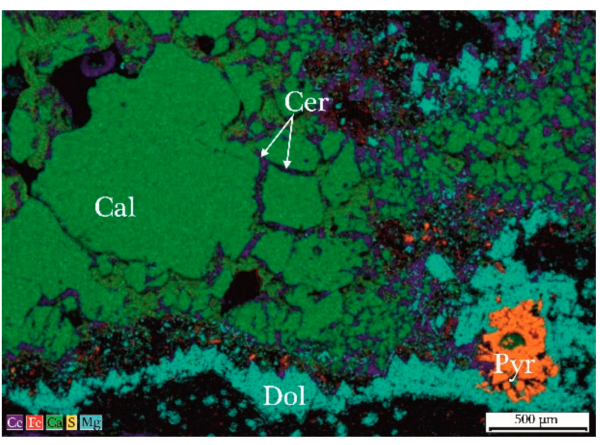

(b)

Figure 4. Elemental maps of $\mathrm{FeK} \alpha, \mathrm{CaK} \alpha, \mathrm{SiK} \alpha, \mathrm{MgK} \alpha, \mathrm{PK} \alpha, \mathrm{SK} \alpha, \mathrm{CeK} \alpha$ : (a) sample 6-1-2 (Syas River in Kolchanovo); (b) sample 4-6 (Popovka River). Cal-calcite, Dol-dolomite, Pyr-pyrite, Fap-fluorapatite, Cer-cerianite-(Ce).

\subsection{Petrography of Anthraconites}

The data from optical studies are in good agreement with data from XRD and EMPA (electron microprobe analyses). Examination of minerals in plane-polarized light and cathodoluminescence shows that the majority of anthraconite bodies contain calcite as the main phase, with minor amounts of dolomite, gypsum, and pyrite. Calcite is usually the main carbonate mineral within the studied samples (samples from Syas and Tyzva Rivers). Calcite form isometric or slightly elongated crystals up to $3 \mathrm{~mm}$ in size (Figure $4 \mathrm{a}, \mathrm{b}$ ). Two calcite phases are observed under the cathodoluminescence microscope. One is dark red or red, with concentric zonation under cathodoluminescence (Cal1 on Figure $5 b)$. The other calcite phase replaces or overgrows the first phase and is always bright orange in CL (Cal2 on Figure 5b).

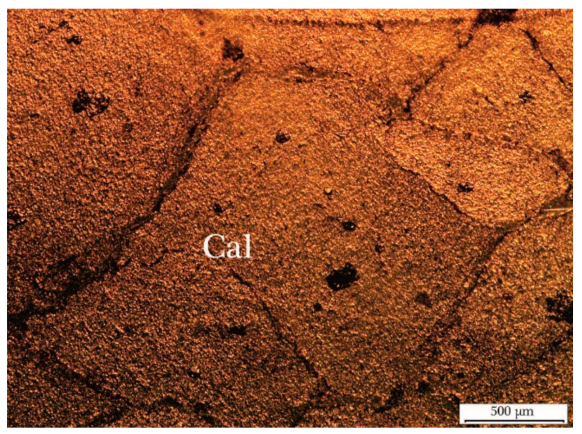

(a)

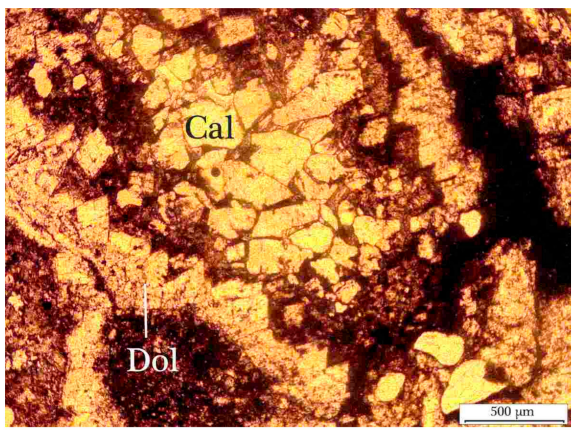

(c)

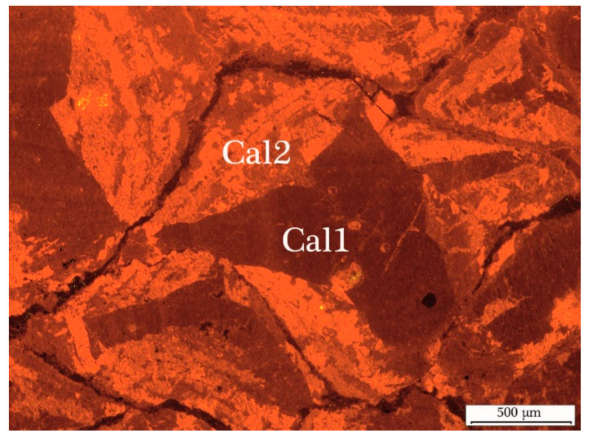

(b)

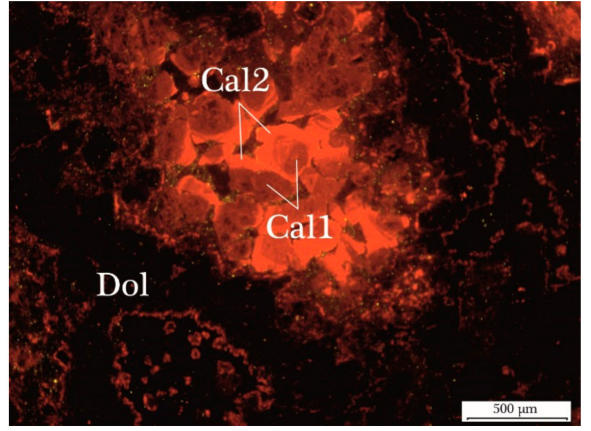

(d)

Figure 5. Petrography and cathodoluminescence (CL) characteristics of the studied carbonate anthraconites: (a) sample 6-1-2 (Syas River), cross-polarized light, (b) the same sample, in CL; (c) sample 4-6 (Popovka River), cross-polarized light, (d) the same sample, in CL; Cal1—the earliest calcite generation (dark red and red zonal in CL), Cal2-the second calcite generation, Cal—calcite, Dol—dolomite. 
Two anthraconite concretions collected along the Suma River are composed of fine ( $>1 \mathrm{~mm})$ dolomite crystals showing dull red cathodoluminescence. Anthraconite samples from Popovka River show the most diverse mineralogical composition, including calcite (crystals up to $1 \mathrm{~mm}$ in diameter are composed of two generations-red to dark red and orange to yellow under cathodoluminescence), dolomite (rhombohedral crystals up to $0.2 \mathrm{~mm}$ in diameter, appearing as black crystals with a thin red fringe under cathodoluminescence), gypsum (fine crystals with no luminescence), and pyrite.

Based on spatial relationships between carbonate phases, the paragenetic sequence of mineral formation can be deciphered. The earliest phase is represented by the calcite with red or dark red CL-colors and concentric zonation. The second phase covers (Figure $5 d$ ) or surrounds (Figure $5 b$ ) the first phase, therefore, postdates it. However, the temporal relationship between dolomite, calcite, and gypsum remains unclear.

\subsection{Stable Isotope Analysis}

Isotopic data from the studied anthraconite samples are shown in Table 3 and Figure 6. For monominerallic calcite nodules, $\delta^{18} \mathrm{O}$ varies from $-7.2 \%$ o to $-5.6 \%$ o V-PDB, whilst $\delta^{13} \mathrm{C}$ varies from $-9.5 \%$ o to $-0.9 \%$ o V-PDB. For dolomite anthraconites, $\delta^{18} \mathrm{O}$ is typically $-3.5 \%$ o V-PDB, whilst $\delta^{13} \mathrm{C}$ varies from $-3.5 \%$ o to $-3.1 \%$ o V-PDB. For polyminerallic samples composed of calcite, dolomite, gypsum, and pyrite in different proportions, $\delta^{18} \mathrm{O}$ varies from $-6.6 \%$ o to $-5.1 \%$ o V-PDB, and $\delta^{13} \mathrm{C}$ varies from $-6.3 \%$ o to $-9.2 \%$ o $\mathrm{V}-\mathrm{PDB}$. There is a negligible correlation between carbon and oxygen isotope values $\left(r^{2}=0.03\right)$.

Table 3. Isotopic data from studied anthraconite samples.

\begin{tabular}{|c|c|c|c|c|c|}
\hline No. & Sample & Location & $\begin{array}{l}\text { Mineral Composition of } \\
\text { Anthraconite Sample }\end{array}$ & $\begin{array}{l}\delta^{18} \mathrm{O} \% \text { o } \\
\text { V-PDB }\end{array}$ & $\begin{array}{l}\delta^{13} \mathrm{C} \% \\
\text { V-PDB }\end{array}$ \\
\hline 1 & $1-1$ & \multirow{2}{*}{ Suma River } & Dolomite & -3.5 & -3.1 \\
\hline 2 & $1-2$ & & Dolomite & -3.5 & -3.5 \\
\hline 3 & $3-1-1$ & \multirow{7}{*}{ Tyzva River } & Calcite & -7.1 & -8.5 \\
\hline 4 & $3-1-2$ & & Calcite & -7.1 & -7.9 \\
\hline 5 & $3-1-3$ & & Calcite & -7.2 & -7.3 \\
\hline 6 & $3-1-4$ & & Calcite & -6.9 & -9.5 \\
\hline 7 & $3-1-5$ & & Calcite & -7.0 & -6.7 \\
\hline 8 & $3-2-1$ & & calcite + gypsum + pyrite & -6.6 & -7.4 \\
\hline 9 & $3-2-8$ & & dolomite + calcite + gypsum & -6.3 & -7.9 \\
\hline 10 & $4-2$ & \multirow{4}{*}{ Popovka River } & calcite + gypsum & -4.9 & -8.4 \\
\hline 11 & $4-3$ & & calcite + gypsum & -5.1 & -7.0 \\
\hline 12 & $4-5$ & & calcite + dolomite + gypsum & -5.1 & -6.3 \\
\hline 13 & $4-6$ & & dolomite + calcite + gypsum & -5.8 & -9.2 \\
\hline 15 & $6-1-1$ & \multirow{5}{*}{$\begin{array}{l}\text { Syas River in } \\
\text { Kolchanovo }\end{array}$} & Calcite & -6.3 & -0.9 \\
\hline 16 & $6-1-2$ & & Calcite & -6.2 & -1.5 \\
\hline 17 & $6-3-2$ & & Calcite & -6.0 & -2.3 \\
\hline 18 & 6-PV-1 & & Calcite & -6.5 & -2.4 \\
\hline 19 & 6-PV-2 & & Calcite & -6.7 & -2.3 \\
\hline 20 & 7-1 & \multirow{6}{*}{$\begin{array}{l}\text { Syas River in } \\
\text { Rebrovo }\end{array}$} & Calcite & -6.4 & -3.7 \\
\hline 21 & $7-2-1$ & & Calcite & -6.3 & -2.2 \\
\hline 22 & $7-2-2$ & & Calcite & -6.3 & -0.9 \\
\hline 23 & $7-3-1$ & & Calcite & -6.0 & -2.2 \\
\hline 24 & $7-3-2$ & & Calcite & -5.6 & -0.9 \\
\hline 25 & $7-3-3$ & & Calcite & -6.2 & -3.2 \\
\hline
\end{tabular}




\section{Discussion}

Our data on the morphology, internal structure, mineralogy, and isotopic composition of Lower Ordovician anthraconites of the Baltic paleobasin reveal many similarities to glendonites. Glendonites are usually found in terrigenous sediments, ranging from mudstones to sandstones ([31-34], amongst others), while modern ikaite crystals are known from muddy deposits [35] and organic-rich sediments [36,37].

There are similarities in morphology between anthraconites (stellate concretions and single crystals) and glendonites (the morphology of glendonites is discussed in several papers, for example $[31,38]$ ). Although brush-like plates have not been described for glendonites, it is conceivable that several adjacent concretions could coalesce to form a broad area of calcite crystals.

The inner structure of studied anthraconite nodules reflects multiple stages of mineral precipitation and allows us to decipher the stages and processes involved in their formation. Three carbonate phases were found within the studied anthraconites. The first phase of calcite is dull red to dark-red and contains concentric zonation in CL, which represent comparable characteristics to calcite often interpreted as being derived from ikaite replacement in glendonite concretions $[31,32,34,38]$. The source of the first calcite phase is therefore likely to be primary ikaite. The second calcite is a cement phase that is characterized by bright CL-colors and precipitated around the earlier ikaite-derived calcite phase. This calcite cement is thought to form from pore waters [31].

The dolomite, found in some anthraconite samples (Suma River), is not a widespread mineral in glendonites, although dolomitized glendonites have been described from Neoproterozoic siliciclastic and carbonate sediments of north-west Canada [39]. The dolomite could have formed by replacement of a portion of the calcite during a later stage of burial diagenesis. Such high dolomite values (up to 99\%) were also reported by Loog [27] in coeval anthraconites from Estonia.

A more complex mineralogical composition of the studied anthraconite samples was found for the samples collected from the Tyzva and Popovka rivers. Petrographic, cathodoluminescence and scanning electron microscope observations, along with $\mathrm{X}$-ray diffraction analyses, reveal a composition including calcite, dolomite, gypsum, and pyrite. We suggest that the complex mineralogical composition of these anthraconites is caused by subsequent post depositional processes. The primary calcite of these anthraconites could have reacted with oxidizing pyrite (pyrite could have been derived from the host rock), resulting in the formation of gypsum (pyrite oxidation, calcite dissolution, and gypsum precipitation in acidic environments has been described by [40,41]). Meanwhile, a supply of $\mathrm{Mg}^{2+}$ and rising $\mathrm{Fe}^{3+}$ concentration could have initiated ferroan dolomite precipitation [42].

Isotopic data from the studied anthraconite samples fall within a narrow range and show values which are comparable to those observed in Mesozoic and Paleozoic glendonites (for details see [34] and references therein). Monominerallic (calcite) and polyminerallic anthraconite samples do not show substantial difference in isotopic ratios. Our data show that all anthraconite samples fall within a narrow range of isotopic values: $\delta^{18} \mathrm{O}$ falls within $-7.2 \%$ o to $-3.5 \%$ o V-PDB, while $\delta^{13} \mathrm{C}$ falls within $-9.5 \%$ o to $-0.9 \%$ o V-PDB (Table 3, Figure 6). According to data published by Greinert and Derkachev [43], during ikaite-glendonite transformation values of $\delta^{18} \mathrm{O}$ do not change significantly, thus glendonite pseudomorphs represent the primary isotopic composition of ikaite and reflect ikaite-water fractionation. In the current study, initial isotopic signal of the ikaite was changed due to influence of ${ }^{18} \mathrm{O}-$ depleted meteoric water during diagenesis (exhumation and weathering). 


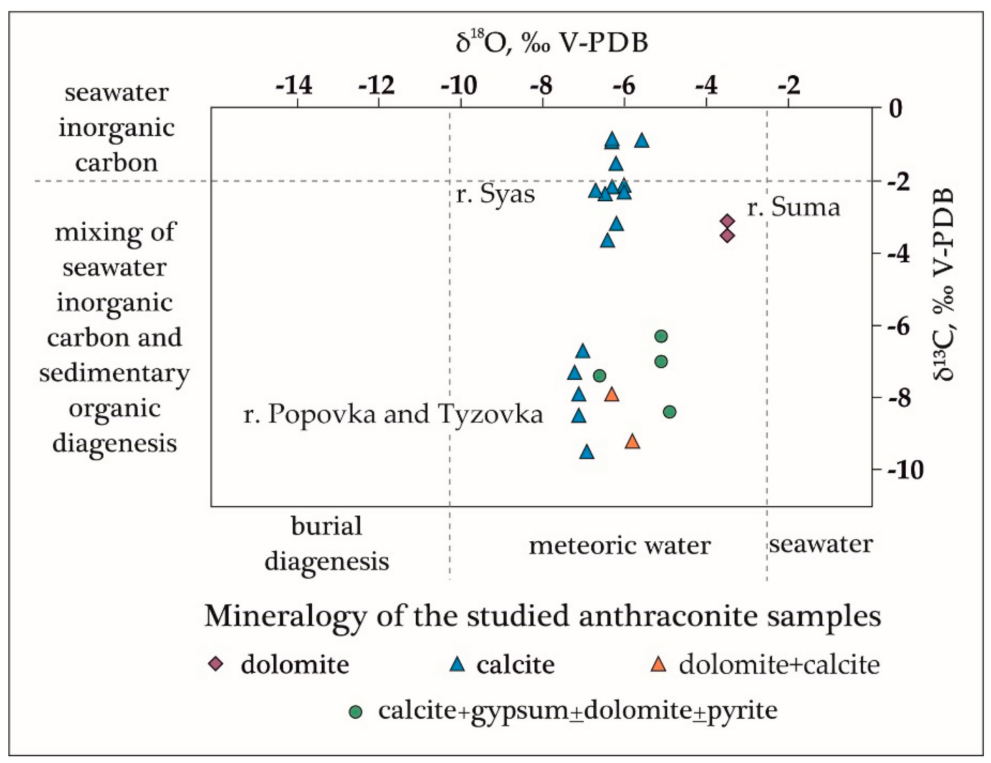

Figure 6. Isotopic composition of anthraconites from the Koporye Formation. Source of carbon and oxygen isotopes are given according to [44].

On the other hand, values of $\delta^{13} \mathrm{C}$ are closely associated to ikaite-glendonite transformations related to bacterial sulfate reduction and/or anaerobic oxidation of methane or organic matter [31,37]. Crystallization of glendonites showing near-zero values of $\delta^{13} \mathrm{C}$ was mostly affected by seawater dissolved inorganic carbon while negative values of $\delta^{13} \mathrm{C}$ are observed in samples where carbon isotopic composition was mostly affected by anaerobic methanotrophy (methane oxidation) and/or degradation of organic matter [45]. Values of $\delta^{13} \mathrm{C}(-9.5 \%$ o to $-0.9 \%$ o V-PDB) obtained for the studied anthraconite samples probably reflect both influence of dissolved inorganic carbon of seawater and oxidation of methane and/or organic matter that confirms published data on glendonite origin.

Therefore, the morphological and isotopic characteristics of the studied anthraconite samples allow us to propose an origin similar to that of glendonites. Glendonite represents the calcite pseudomorph of ikaite, a mineral which is often used as an indicator of cold climates due to their common association with glacial deposits [46]. Glendonites are often used as a paleoclimate indicator for reconstructing near-freezing conditions [33,38,47-49], although the main controlling factors on ikaite precipitation are still debated. Temperature and orthophosphate concentration are believed to play major roles in ikaite precipitation, with natural ikaite precipitation taking place in temperatures ranging from $0{ }^{\circ} \mathrm{C}$ to $4{ }^{\circ} \mathrm{C}$ [47]. However, in natural environments ikaite is thought to be stable under temperatures of $7-10^{\circ} \mathrm{C}[38,50]$, while laboratory experiments have revealed that ikaite precipitation can occur in temperatures as warm as $15^{\circ} \mathrm{C}$ [51]. Organic-rich sediments along with low temperature may have an impact on ikaite precipitation too: in organic-rich sediments ikaite precipitation can be favored by releasing of bicarbonate and high phosphate concentration due to anaerobic oxidation of methane and/or organic matter [52].

In the Early Ordovician, the Baltica paleocontinent was slowly drifting through the mid-low latitudes towards the equator, and was characterized by a relatively warm climate [1]. At the beginning of the Early Ordovician, the study area was part of a large paleobasin which extended to present-day Poland and northern Norway [53], but with shallow water depths in the Russian part [54-56]. A warm greenhouse climate instigated high rates of surface water evaporation, resulting in the Baltic paleobasin becoming temperature stratified [56]. Such basins are characterized by a high surface-to-deep temperature gradient, with cold and poorly ventilated bottom waters, anoxic conditions and clay/mud deposition [56]. However, it was shown that in shallow water stratified basins pycnocline can deepen thus increasing bottom-water temperature [57]. The input of cold water rich in phosphate could have been associated with upwelling currents. In the Early Ordovician, upwelling zones are defined along 
paleocontinental margins, including Baltica, leading to black shales sedimentation [58] and expanding of graptoloid fauna [59]. Therefore, the occurrence of glendonites in the Upper Cambrian-Lower Ordovician deposits of the Baltic basin do not coincide with other cold climate indicators. Consequently, we propose that the presence of glendonites is evidence for cold bottom waters (of at least up to $7-10^{\circ} \mathrm{C}$ ) rather than for a globally cold climate. In the study area, Ordovician bottom water temperatures may have been analogous to modern Gulf Stream bottom water temperatures of $<16^{\circ} \mathrm{C}$ (for details see [59] and references therein). The resulting low temperatures and elevated orthophosphate concentrations provided favorable conditions for ikaite precipitation across the north-western margin of Baltica. Subsequent burial and phases of diagenesis then resulted in the transformation of ikaite into calcite and its cementation (Figure 7). It should be noted that similar stellate anthraconites related to ikaite are also known from the Upper Cambrian of Sweden (i.e., [7], Figures 73-76 therein), as well as from the Lower Ordovician of Poland [60]. Therefore, specific conditions favorable for ikaite precipitation existed across Baltoscandia during a relatively long time interval spanning at least the latest Cambrian to early Tremadocian, and occupied a significant part of the shallow sea basin.

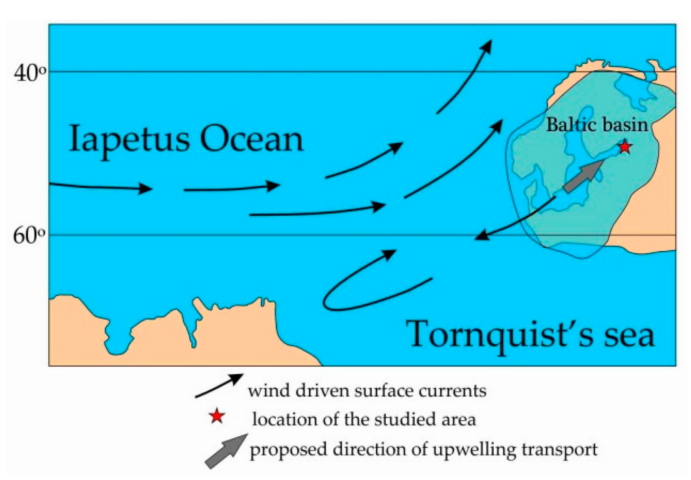

(a)

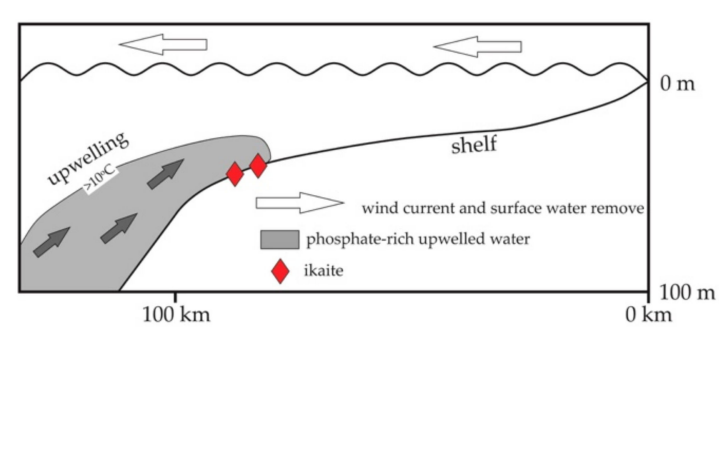

(b)

Figure 7. (a) Iapetus Ocean circulation model in the Tremadocian based on [59], (b) upwelling model for the Baltic epicontinental sea in the Early Ordovician.

\section{Conclusions}

1. The morphology, internal structure, petrographic and cathodoluminescence characteristics suggest that the anthraconites were precipitated as primary ikaite, which was subsequently replaced by calcite and later partly by dolomite.

2. The negative stable carbon isotopic ratios show that ikaite-glendonite transformation was influenced by methane and/or organic matter degradation. Thus, there were three intermixed sources of carbon isotopes-dissolved inorganic carbon from seawater, degradation of organic matter, and/or methanotrophy. The oxygen isotope ratios do not reflect isotopic composition of the ikaite and probably was changed during diagenesis by meteoric water.

3. Based on our mineralogical, petrographic, cathodoluminescence, and isotopic data, along with the stratigraphic position of the studied samples, we propose a new model for the formation of anthraconites in the Baltic paleobasin. Our model invokes the precipitation of ikaite in an upwelling zone along the western margin of Baltica (modern co-ordinates), which brought deep cold phosphate-rich waters up to shallower water depths, providing favorable conditions for ikaite precipitation within the relatively shallow Baltic paleobasin. The unstable ikaite was subsequently transformed to calcite and/or dolomite during diagenesis under reducing conditions that were probably favored by degradation of organic matter and/or methanotrophy.

4. The complex mineralogical composition of the studied anthraconite samples was formed during early diagenesis under reducing conditions (calcite + pyrite), and by oxidative processes during diagenesis, when calcite and pyrite were transformed to gypsum and dolomite. The source of cerianite observed in the fractures remains unclear. 
Author Contributions: Formal analysis, O.V. and B.P.; Investigation, K.M.; Project administration and Supervision, V.E.; Resources, P.F.; Validation, M.R.; Visualization, K.V.; Writing—original draft, K.M.; Writing—review \& editing, K.V., V.E., P.F., O.V. and M.R.

Acknowledgments: The authors thank the Resource Center of X-ray diffraction studies and Geomodel Resource Centre of Saint-Petersburg State University for providing instrumental and computational resources. Special thanks to James Barnet (Camborne School of Mines) for constructing comments and correcting the English.

Conflicts of Interest: The authors declare no conflict of interest. The funders had no role in the design of the study; in the collection, analyses, or interpretation of data; in the writing of the manuscript, or in the decision to publish the results.

\section{References}

1. Torsvik, T.H.; Cocks, L.R. Earth History and Palaegeography; Cambridge University Press: Cambridge, UK, 2016; pp. 1-332.

2. Thompson, C.K.; Kah, L.C. Sulfur isotope evidence for widespread euxinia and a fluctuating oxycline in Early to Middle Ordovician greenhouse oceans. Palaeogeogr. Palaeoclimatol. Palaeoecol. 2012, 313-314, $189-214$. [CrossRef]

3. Saltzman, M.R.; Edwards, C.T.; Adrain, J.M.; Westrop, S.R. Persistent oceanic anoxia and elevated extinction rates separate the Cambrian and Ordovician radiations. Geology 2015, 43, 807-811. [CrossRef]

4. Edwards, C.T.; Fike, D.A.; Saltzman, M.R.; Lu, W.; Lu, Z. Evidence for local and global redox conditions at an Early Ordovician (Tremadocian) mass extinction. Earth Planet. Sci. Lett. 2018, 481, 125-135. [CrossRef]

5. Buchardt, B.; Nielsen, A.T. Carbon and oxygen isotope composition of Cambro-Silurian limestone and anthraconite from Bornholm: Evidence for deep burial diagenesis. Bull. Geol. Soc. Den. 1985, 33, 415-435.

6. Schmidt, F. Revision der ostbaltischen silurischen Trilobiten nebst geognostischer Übersicht des ostbaltischen Silurgebiets. Abtheilung I.; Phacopiden, Cheiruriden und Encrinuriden. Mémoires De L'académie Impériale Des Sci. De St.-Pétersbourg. VIIe Série 1882, 30, 1-255.

7. Hadding, A. The Pre-Quaternary Sedimentary Rocks of Sweden. VII. Cambrian and Ordovician Limestones; Lund CWK Gleerup: Lund, Sweden, 1958.

8. Berg-Madsen, V. Origin and usage of the geological terms orsten, stinkstone, and anthraconite. Arch. Nat. Hist. 1989, 16, 191-208. [CrossRef]

9. Lindström, M. White sand crosses in turbated siltstone bed, basal Cambrian, Kinnekulle, Sweden. Geol. Palaeontol. 1977, 11,1-8.

10. Lindström, M. Cold age sediment in Lower Cambrian of South Sweden. Geol. Palaeontol. 1972, 6, 9-23.

11. Lindström, M. Do "white sand crosses" from the Lower Cambrian of Kinnekulle have glendonite affinity? Geol. Föreningen i Stockh. Förhandlingar 1984, 106, 32. [CrossRef]

12. Stolley, E. Pseudo-Gaylussit, Pseudo-Pirssonit und Protospongia im cambrischen Alaunschiefer Bornholms. Medd. fra Dan. Geol. Foren. 1909, 15, 351-368. [CrossRef]

13. Callisen, K. Tenformede Tungspatkrystaller ("Pseudo-Gaylussit" og "Pseudo-Pirssonit") i Alunskiferen. Medd. fra Dan. Geol. Foren. 1914, 4, 245-258.

14. Choh, S.J. First report of glendonite in the uppermost Cambrian. Proceedings of GSA Annual Meeting in Indianapolis, Indiana, IN, USA, 4-7 November 2018.

15. Brøgger, W.C. Die Silurischen Etagen 2 und 3 im Kristianiagebiet und auf Eker, ihre Gliederung, Fossilien, Schichtenstörungen und Contactmetamorphosen; A.W. Brögger: Oslo, Norway, 1882.

16. Calner, M.; Erlström, M.; Lehnert, O.; Ahlberg, P. Lower Palaeozoic geology of southern Sweden. In The Lower Palaeozoic of Southern Sweden and the Oslo Region, Norway; Calner, M., Ahlberg, P., Eds.; Geological Survey of Sweden: Stockholm, Sweden, 2013; pp. 6-9.

17. Trotter, J.A.; Williams, I.S.; Barnes, C.R.; Lécuyer, C.; Nicoll, R.S. Did cooling oceans trigger Ordovician biodiversification? Evidence from conodont thermometry. Science 2008, 321, 550-554. [CrossRef] [PubMed]

18. Hearing, T.W.; Harvey, T.H.; Williams, M.; Leng, M.J.; Lamb, A.L.; Wilby, P.R.; Gabbott, S.E.; Pohl, A.; Donnadieu, Y. An early Cambrian greenhouse climate. Sci. Adv. 2018, 4, 1-11. [CrossRef] [PubMed]

19. Babcock, L.E.; Peng, S.C.; Brett, C.E.; Zhu, M.Y.; Ahlberg, P.; Bevis, M.; Robison, R.A. Global climate, sea level cycles, and biotic events in the Cambrian Period. Palaeoworld 2015, 24, 5-15. [CrossRef] 
20. Landing, E.; MacGabhann, B.A. First evidence for Cambrian glaciation provided by sections in Avalonian New Brunswick and Ireland: Additional data for Avalon-Gondwana separation by the earliest Palaeozoic. Palaeogeogr. Palaeoclimatol. Palaeoecol. 2010, 285, 174-185. [CrossRef]

21. Le Heron, D.P.; Vandyk, T.M.; Wu, G.; Li, M. New perspectives on the Luoquan Glaciation (Ediacaran-Cambrian) of North China. Depos. Rec. 2018, 4, 274-292. [CrossRef]

22. Runkel, A.C.; Mackey, T.J.; Cowan, C.A.; Fox, D.L. Tropical shoreline ice in the late Cambrian: Implications for Earth's climate between the Cambrian Explosion and the Great Ordovician Biodiversification Event. Gsa Today 2010, 20, 4-10. [CrossRef]

23. Verbitskii, V.R.; Verbitskii, I.V.; Vasilyeva, O.V.; Savanin, V.V.; Kyamyarya, V.V.; Mazurkevich, K.N.; Krotova-Putintzeva, A.E.; Semyenova, L.R.; Bogdanov, Y.B.; Petrov, B.V. State Geological Map of Russian Federation. Map Scale 1:1 000 000. Sheets O-35-Pskov, (N-35), O-36-Saint-Petersburg. Explanatory Notes; Cartographic Factory VSEGEI: Saint Petersburg, Russia, 2012; 510p. (In Russian)

24. Geology of USSR. Leningrad, Pskov, Novgorod regions. Geological description. North-West local GU.; Nedra: Moscow, Russia, 1971; p. 504. (In Russian)

25. State geological map of USSR. Map scale 1:1 000 000. Sheets O-(35), 36 Leningrad. Explanatory notes.; Cartographic Factory VSEGEI: Leningrad, Russia, 1989; p. 212. (In Russian)

26. Popov, L.E.; Khazanovich, K.K. Key Sections and Stratigraphy of Cambrian-Ordovician Phosphate-Bearing Obolus Sandstone on the North-Western of the Russian Platform; Nauka: Leningrad, Russia, 1989; p. 222. (In Russian)

27. Loog, A. On the geochemistry of postsedimentary mineral formation in the Tremadoc graptolitic argillites of North Estonia. Acta et Comment. Univ. Tartu. 1980, 527, 44-50.

28. Tugarova, M.A.; Platonov, M.V. Carbonate microbioliths in the Koporye Formation argillites of north-west flank of the Moscow symiclise. Lithosphere 2014, 4, 36-49. (In Russian)

29. Popov, L.E.; Alvaro, J.J.; Holmer, L.E.; Bauert, H.; Pour, M.G.; Dronov, A.V.; Lehnert, O.; Hints, O.; Mannik, P.; Zhang, Z.; et al. Glendonite occurences in the Tremadocian of Baltica: First Early Palaeozoic evidence of massive ikaite precipitation at temperature latitudes. Sci. Rep. 2019, 9, 7205. [CrossRef]

30. Zaitsev, A.V.; Pokrovsky, B.G. Carbon and oxygen isotope compositions of Lower-Middle Ordovician carbonate rocks in the northwestern Russian platform. Lithol. Miner. Resour. 2014, 49, 283-291. [CrossRef]

31. Teichert, B.M.A.; Luppold, F.W. Glendonites from an Early Jurassic methane seep-climate or methane indicators? Palaeogeogr. Palaeoclimatol. Palaeoecol. 2013, 390, 81-93. [CrossRef]

32. Morales, C.; Rogov, M.; Wierzbowski, H.; Ershova, V.; Suan, G.; Adatte, T.; Föllmi, K.B.; Tegelaar, E.; Reichart, G.J.; de Lange, G.J.; et al. Glendonites track methane seepage in Mesozoic polar seas. Geology 2017, 45, 503-506. [CrossRef]

33. Rogov, M.A.; Ershova, V.B.; Shchepetova, E.V.; Zakharov, V.A.; Pokrovsky, B.G.; Khudoley, A.K. Earliest Cretaceous (late Berriasian) glendonites from Northeast Siberia revise the timing of initiation of transient Early Cretaceous cooling in the high latitudes. Cretac. Res. 2017, 71, 102-112. [CrossRef]

34. Vickers, M.; Watkinson, M.; Price, G.D.; Jerret, R. An improved model for the ikaite-glendonite transformation: Evidence from the Lower Cretaceous of Spitsbergen, Svalbard. Norw. J. Geol. 2018, 98, 1-15. [CrossRef]

35. Derkachev, A.N.; Nikolaeva, N.A.; Mozherovsky, A.V.; Grigor'eva, T.N.; Ivanova, E.D.; Pletnev, S.P.; Barinov, N.N.; Chubarov, V.M. Mineralogical and geochemical indicators of anoxic sedimentation conditions in local depressions within the Sea of Okhotsk in the Late Pleistocene-Holocene. Russ. J. Pac. Geol. 2007, 1, 203-229. [CrossRef]

36. Suess, E.; Balzer, W.; Hesse, K.F.; Muller, P.J.; Ungerer, C.A.; Wefer, G. Calcium carbonate hexahydrate from organic-rich sediments of the Antarctic Shelf: Precursors of glendonites. Science 1982, 216, 1128-1131. [CrossRef]

37. Kodina, L.A.; Tokarev, V.G.; Vlasova, L.N.; Korobeinik, G.S. Contribution of biogenic methane to ikaite formation in the Kara Sea; evidence from the stable carbon isotope geochemistry. Proc. Mar. Sci. 2003, 6, 349-374.

38. Frank, T.D.; Tomas, S.G.; Fielding, C.R. On using carbon and oxygen isotope data from glendonites as paleoenvironmental proxies: A case study from the Permian system of eastern Australia. J. Sediment. Res. 2008, 78, 713-723. [CrossRef]

39. James, N.P.; Narbonne, G.M.; Dalrymple, R.W.; Kyser, T.K. Glendonites in Neoproterozoic low latitude, interglacial, sedimentary rocks, northwest Canada: Insights into the Cryogenian ocean and Precambrian cold-water carbonates. Geology 2005, 33, 9-12. [CrossRef] 
40. Joeckel, R.M.; Ang Clement, B.J.; VanFleet Bates, L.R. Sulfate-mineral crusts from pyrite weathering and acid rock drainage in the Dakota Formation and Graneros Shale, Jefferson Country, Nebraska. Chem. Geol. 2005, 15, 433-452. [CrossRef]

41. Ritsema, C.J.; Groenenberg, J.E. Pyrite oxidation, carbonate weathering, and gypsum formation in a drained potential acid sulfate soil. Soil Sci. Soc. Am. J. 1993, 57, 968-976. [CrossRef]

42. Machel, H.G. Concepts and models of dolomitization: A critical reappraisal. In The Geometry and Petrogenesis of Dolomite Hydrocarbon Reservoirs; Braothwaite, C.J.R., Rizzi, G., Eds.; Geological Society, London, Special Publications: London, UK, 2004; Volume 235, pp. 7-63.

43. Greinert, J.; Derkachev, A. Glendonites and methane-derived Mg-calcites in the Sea of Okhotsk, Eastern Siberia: Implications of a venting-related ikaite/glendonite formation. Mar. Geol. 2004, 204, 129-144. [CrossRef]

44. Campbell, K.A. Hydrocarbon seep and hydrothermal vent paleoenvironments and paleontology: Past developments and future research directions. Palaeogeogr. Palaeoclimatol. Palaeoecol. 2006, 232, 362-407. [CrossRef]

45. Coleman, M.L. Microbial processes: Controls on the shape and composition of carbonate concretions. Mar. Geol. 1993, 113, 127-140. [CrossRef]

46. Kaplan, M.E. Calcite pseudomorph in Jurassic and Lower Cretaceous deposit of the north part of East Siberia. Geol. Geofiz. 1978, 12, 62-70. (In Russian)

47. De Lurio, J.L.; Frakes, L.A. Glendonites as a paleoenvironmental tool: Implications for early Cretaceous high latitude climates in Australia. Geochim. Cosmochim. Acta 1999, 63, 1039-1048. [CrossRef]

48. Selleck, B.W.; Carr, P.F.; Jones, B.G. A review and synthesis of glendonites (pseudomorphs after ikaite) with new data: Assessing applicability as recorders of ancient coldwater conditions. J. Sediment. Res. 2007, 77, 980-991. [CrossRef]

49. Price, G.D.; Nunn, E.V. Valanginian isotope variation in glendonites and belemnites from Arctic Svalbard: Transient glacial temperatures during the Cretaceous greenhouse. Geology 2010, 38, 251-254. [CrossRef]

50. Zhou, X.; Lu, Z.; Rickaby, R.E.M.; Domack, E.W.; Wellner, J.S.; Kennedy, H.A. Ikaite abundance controlled by porewater phosphorous level: Potential links to dust and productivity. J. Geol. 2015, 123, 269-281. [CrossRef]

51. Stockmann, G.J.; Ranta, E.; Trampe, E.; Sturkell, E.; Seaman, P. Carbon mineral storage in seawater: Ikaite $\left(\mathrm{CaCO}_{3} \cdot 6 \mathrm{H}_{2} \mathrm{O}\right)$ columns in Greenland. Energy Procedia 2018, 146, 59-67. [CrossRef]

52. Qu, Y.; Teichert, B.M.A.; Birgel, D.; Goedert, J.L.; Peckmann, J. The prominent role of bacterial sulfate reduction in the formation of glendonite: A case study from Paleogene marine strata of western Washington State. Facies 2017, 63, 10. [CrossRef]

53. Buchardt, B.; Nielsen, A.T.; Schovsbo, N.H. Alun Skiferen i Skandinavien. Geol. Tidsskr. 1997, 3, 1-30. (In Danish)

54. Dronov, A.; Holmer, L. Ordovician sea-level curve: Baltoscandian view. In Proceedings of the Basin Stratigraphy-Modern Methods and Problems, 5th Baltic Stratigraphical Congress, Vilnius, Lithuania, 22-27 September 2002; pp. 33-35.

55. Haq, B.U.; Schutter, S.R. A chronology of Paleozoic sea-level changes. Science 2008, 322, 64-68. [CrossRef] [PubMed]

56. Vyalov, V.I.; Larichev, A.I.; Balakhonova, A.S. Ore genesis of Dictionema shale and Obolus sandstones of the Baltic basin. Reg. Geol. Metallog. 2013, 55, 87-98.

57. Kelly, J.R.; Doering, P.H. Seasonal deepening of the pycnocline in a shallow shelf ecosystem and its influence on near-bottom dissolved oxygen. Mar. Ecol. Prog. Ser. 1999, 178, 151-168. [CrossRef]

58. Trabucho-Alexandre, J.; Hay, W.W.; De Boer, P.L. Phanerozoic environments of black shale deposition and the Wilson Cycle. Solid Earth 2011, 3, 29-42. [CrossRef]

59. Cooper, R.A.; Rigby, S.; Loydell, D.K.; Bates, D.E.D. Palaeoecology of the Graptoloidea. Earth-Sci. Rev. 2012, 112, 23-41. [CrossRef]

60. Modliński, Z.; Szymański, B. The Ordovician lithostratigraphy of the Peribaltic Depression (NE Poland). Kwart. Geol. 1997, 41, 273-288.

(C) 2019 by the authors. Licensee MDPI, Basel, Switzerland. This article is an open access article distributed under the terms and conditions of the Creative Commons Attribution (CC BY) license (http://creativecommons.org/licenses/by/4.0/). 